\title{
Synthesis and Characterization of Metal Tribromoacetates and Their Alkali Metal Derivatives
}

\author{
Jugal Kishore Puri, ${ }^{1}$ and Rajni Chhoker ${ }^{2}$ \\ ${ }^{1}$ Centre of Advanced Studies and Department of Chemistry, Panjab University, Chandigarh 160014, India \\ ${ }^{2}$ Chemistry Department, Mewar University, Chittorgarh, Rajasthan, India
}

Correspondence should be addressed to Jugal Kishore Puri; prof_jkpuri@yahoo.com

Received 13 June 2012; Accepted 2 July 2012

Academic Editor: Elena Gomez

Copyright ( 2013 J. K. Puri and R. Chhoker. This is an open access article distributed under the Creative Commons Attribution License, which permits unrestricted use, distribution, and reproduction in any medium, provided the original work is properly cited.

Complexes of composition $\mathrm{Fe}_{2} \mathrm{Cl}_{2}\left(\mathrm{O}_{2} \mathrm{CCBr}_{3}\right)_{4}, \mathrm{Fe}_{2} \mathrm{Cl}\left(\mathrm{O}_{2} \mathrm{CCBr}_{3}\right)_{5}, \mathrm{Fe}\left(\mathrm{O}_{2} \mathrm{CCBr}_{3}\right)_{3},\left[\left(\mathrm{Me}_{4} \mathrm{~N}\right)_{2}\right]\left[\mathrm{Fe}\left(\mathrm{O}_{2} \mathrm{CCBr}_{3}\right)_{4}\right], \mathrm{K}\left[\mathrm{Fe}\left(\mathrm{O}_{2} \mathrm{CCBr}\right)_{4}\right]$, $\mathrm{Rb}\left[\mathrm{Fe}\left(\mathrm{O}_{2} \mathrm{CCBr}_{3}\right)_{4}\right], \mathrm{Cs}\left[\mathrm{Fe}\left(\mathrm{O}_{2} \mathrm{CCBr}_{3}\right)_{4}\right],\left[\left(\mathrm{Me}_{4} \mathrm{~N}\right)_{2}\right]\left[\mathrm{Co}\left(\mathrm{O}_{2} \mathrm{CCBr}_{3}\right)_{4}\right],\left[\left(\mathrm{Me}_{4} \mathrm{~N}\right)_{2}\right]\left[\mathrm{Mn}\left(\mathrm{O}_{2} \mathrm{CCBr}\right)_{4}\right],\left[\left(\mathrm{Me}_{4} \mathrm{~N}\right)_{2}\right]\left[\mathrm{Cu}\left(\mathrm{O}_{2} \mathrm{CCBr}\right)_{4}\right]$, and $\left[\left(\mathrm{Me}_{4} \mathrm{~N}\right)_{2}\right]\left[\mathrm{Ni}\left(\mathrm{O}_{2} \mathrm{CCBr}_{3}\right)_{4}\right]$ have been prepared by metathetical reactions using nitromethane as solvent. All these compounds have been characterized by elemental analysis, molar conductance, infrared, reflectance and thermogravimetric studies.

\section{Introduction}

In continuation of our previous studies [1-8] of the solvolytic reactions and synthesis of bromoacetates of metals such as $\mathrm{Ti}(\mathrm{IV}), \mathrm{V}(\mathrm{III}), \mathrm{Cr}(\mathrm{III}), \mathrm{Al}(\mathrm{III})$, and $\mathrm{Mn}(\mathrm{II})$, and their complexes with various bases, in the present investigation, we report the synthesis of iron (III), cobalt(II), nickel(II), copper(II), and manganese(II) tribromoacetates and their alkali metal derivatives. Synthesis, reactivity, and structures of mono- and dihaloacetato complexes of copper(I) and copper(II) have been reported [9]. Recently the synthesis of coordination compounds via dehalogenation of zinc bromoacetate in presence of some amines have also been reported [10]. Anhydrous iron(III) chloride and bromide solvolyse in acetic acid to form $\mathrm{FeX}\left(\mathrm{O}_{2} \mathrm{CCH}_{3}\right) \cdot \mathrm{nH}_{2} \mathrm{O}$, where $\mathrm{X}=\mathrm{Cl}^{-}, \mathrm{Br}^{-}$ [11]. Iron(III) chloride forms $\mathrm{Fe}_{3} \mathrm{Cl}_{3}\left(\mathrm{O}_{2} \mathrm{CCH}_{3}\right)_{6} \cdot \mathrm{HO}_{2} \mathrm{CCH}_{3}$ [12] on heating with acetic acid. These observations could not be repeated. At room temperature iron(III) chloride with acetic acid gives $\mathrm{Fe}_{2}(\mathrm{OH})_{2} \mathrm{Cl}_{2}\left[\mathrm{O}_{2} \mathrm{CCH}_{3}\right]_{2} \cdot 2 \mathrm{HO}_{2} \mathrm{CCH}_{3}$. $\mathrm{H}_{2} \mathrm{O}$ while it forms $\mathrm{Fe}_{2}(\mathrm{OH})_{2} \mathrm{Cl}_{2}\left[\mathrm{O}_{2} \mathrm{CCH}_{3}\right]_{2} \cdot 2 \mathrm{HO}_{2} \mathrm{CCH}_{3}$ at $130^{\circ} \mathrm{C}$. Inspite of perfectly anhydrous reagent and dry condition, water was always introduced in the reaction. This concludes that affinity of $\mathrm{Fe}^{3+}$ ion for water is so strong that it can abstract water from anhydrous acetic acid. Anhydrous
iron(III) acetate was prepared metathetically from iron(III) chloride and silver acetate in tetrahydrofuran [13]. Anhydrous iron(III) triflouroacetate was prepared from iron(III) chloride and silver triflouroacetate [14] in nitromethane.

The reaction of anhydrous iron(III) chloride with fused tribromoacetic acid in different stoichiometric ratios have been carried out. The resulting compounds were characterized by their elemental analysis, molar conductance, infrared, and thermogravimetric studies. The molar ratios of various reactants has been very carefully controlled and the reaction time also needs to be carefully observed.

\section{Experimental}

2.1. Preparation of $\mathrm{Fe}_{2} \mathrm{Cl}_{2}\left(\mathrm{O}_{2} \mathrm{CCBr}_{3}\right)_{4}$ and $\mathrm{Fe}_{2} \mathrm{Cl}\left(\mathrm{O}_{2} \mathrm{CCBr}_{3}\right)_{5}$. Anhydrous Iron (III) chloride $(3.25 \mathrm{~g}, 20 \mathrm{mmol})$ was refluxed with tribromoacetic acid $(4.88 \mathrm{~g}, 40 \mathrm{mmol})$ in $\mathrm{CCl}_{4}$ under nitrogen atmosphere for about 8 hours. A yellow coloured solid compound separated out. It was filtered and washed with dichloromethane. The solid was finally dried under vacuum. Elemental analysis corresponds to the composition $\mathrm{Fe}_{2} \mathrm{Cl}_{2}\left(\mathrm{O}_{2} \mathrm{CCBr}_{3}\right)_{4}$.

The compound $\mathrm{Fe}_{2} \mathrm{Cl}_{2}\left(\mathrm{O}_{2} \mathrm{CCBr}_{3}\right)_{4}(4.101 \mathrm{~g}, 3 \mathrm{mmol})$ was refluxed with fused tribromoacetic acid $(0.89 \mathrm{~g}, 3 \mathrm{mmol})$ in 
TABLE 1: Amount, colours, yields, and analysis of $\left(\mathrm{Me}_{4} \mathrm{~N}\right)_{2} \mathrm{MCl}_{4},(\mathrm{M}=\mathrm{Mn}, \mathrm{Co}, \mathrm{Ni}, \mathrm{Cu})$.

\begin{tabular}{|c|c|c|c|c|c|c|c|}
\hline \multirow{2}{*}{ Anhydrous metal chloride } & \multirow{2}{*}{$\begin{array}{c}\text { Weight } \\
\mathrm{g}(\mathrm{mmol})\end{array}$} & \multirow{2}{*}{$\begin{array}{c}\text { Wt. of }\left(\mathrm{Me}_{4} \mathrm{~N}\right) \mathrm{Cl} \\
\mathrm{g}(\mathrm{mmol})\end{array}$} & \multirow{2}{*}{ Product obtained } & \multirow{2}{*}{ Colour of product } & \multirow{2}{*}{$\begin{array}{c}\text { Yield } \\
(\%)\end{array}$} & \multicolumn{2}{|c|}{ Analysis found (calculated) } \\
\hline & & & & & & M & $\mathrm{Cl}$ \\
\hline $\mathrm{MnCl}_{2}$ & $1.259(10.00)$ & $2.19(20.00)$ & $\left(\mathrm{Me}_{4} \mathrm{~N}\right)_{2} \mathrm{MnCl}_{4}$ & Light green & 78 & $15.72(15.93)$ & $40.90(41.16)$ \\
\hline $\mathrm{CoCl}_{2}$ & $1.299(10.00)$ & $2.19(20.00)$ & $\left(\mathrm{Me}_{4} \mathrm{~N}\right)_{2} \mathrm{CoCl}_{4}$ & Blue & 78 & $16.74(16.88)$ & $40.24(40.69)$ \\
\hline $\mathrm{NiCl}_{2}$ & 1.307 (10.00) & $2.19(20.00)$ & $\left(\mathrm{Me}_{4} \mathrm{~N}\right)_{2} \mathrm{NiCl}_{4}$ & Greenish & 68 & $16.46(16.83)$ & $40.43(40.72)$ \\
\hline $\mathrm{CuCl}_{2}$ & $1.3455(10.00)$ & $2.19(20.00)$ & $\left(\mathrm{Me}_{4} \mathrm{~N}\right)_{2} \mathrm{CuCl}_{4}$ & Dark yellow & 81 & $17.58(17.96)$ & $40.09(40.17)$ \\
\hline
\end{tabular}

carbon tetrachloride for 6 hours with constant stirring. A light pink solid separated out. It was filtered and washed with dichloromethane and finally dried under vacuum. Elemental analysis gave the composition $\mathrm{Fe}_{2} \mathrm{Cl}\left(\mathrm{O}_{2} \mathrm{CCBr}_{3}\right)_{5}$.

Finally, $\mathrm{Fe}_{2} \mathrm{Cl}\left(\mathrm{O}_{2} \mathrm{CCBr}_{3}\right)_{5}(3.255 \mathrm{~g}, 2 \mathrm{mmol})$ was refluxed with excess of tribromoacetic acid $(0.594 \mathrm{~g}, 2 \mathrm{mmol})$ in carbon tetrachloride till the evolution of $\mathrm{HCl}$ gas ceased and whole of the solid dissolved to give an orange coloured solution. The solution was evaporated to dryness and an orange red compound $\mathrm{Fe}\left(\mathrm{O}_{2} \mathrm{CCBr}_{3}\right)_{3}$ was obtained. This compound was also prepared by direct refluxing of anhydrous iron(III) chloride with excess of tribromoacetic acid by a method analogous to reported in literature [6].

2.2. Preparation of Tetramethylammonium tetrachloroferrate(III), That Is, $\left[\mathrm{Me}_{4} \mathrm{~N}\right]\left[\mathrm{FeCl}_{4}\right]$. Anhydrous iron(III) chloride $(1.62 \mathrm{~g}, 10 \mathrm{mmol})$ was mixed with tetramethylammonium chloride in carbon tetrachloride $(30 \mathrm{~mL})$. The contents were refluxed for 4 hours. Yellow coloured solid formed was filtered and washed with dichloromethane and then dried under vacuum. (Yield 80\%, Found: $\mathrm{Fe}=20.25, \mathrm{Cl}=51.80$; Calculated for $\left[\mathrm{Me}_{4} \mathrm{~N}\right]\left[\mathrm{FeCl}_{4}\right] \mathrm{Fe}=20.54, \mathrm{Cl}=52.23 \%$ ).

2.3. Preparation of $\left[\mathrm{Me}_{4} \mathrm{~N}\right]\left[\mathrm{Fe}\left(\mathrm{O}_{2} \mathrm{CCBr}_{3}\right)_{4}\right]$. $\left[\mathrm{Me}_{4} \mathrm{~N}\right]\left[\mathrm{FeCl}_{4}\right]$ $(2.72 \mathrm{~g}, 10 \mathrm{mmol})$ in nitromethane was taken in round bottom flask equipped with anhydrous calcium chloride guard tube. To this was added silver tribromoacetate $(16.16 \mathrm{~g}$, $40 \mathrm{mmol}$ ). The resulting solution was evaporated to dryness and solid thus obtained was kept in diethylether and stirred well for 4 hours. Finally the solid mass was filtered and dried under vacuum in an atmosphere of nitrogen. This is a dark red coloured compound, insoluble in common organic solvents but soluble in nitromethane and acetonitrile.

2.4. Preparation of $\mathrm{K}\left[\mathrm{Fe}\left(\mathrm{CBr}_{3} \mathrm{COO}\right)_{4}\right], \mathrm{Rb}\left[\mathrm{Fe}\left(\mathrm{CBr}_{3} \mathrm{COO}\right)_{4}\right]$, and $\mathrm{Cs}\left[\mathrm{Fe}\left(\mathrm{CBr}_{3} \mathrm{COO}\right)_{4}\right]$. Potassium chloride, rubidium chloride, and cesium bromide $(0.745 \mathrm{~g}, 10 \mathrm{mmol} ; 1.21 \mathrm{~g}$, $10 \mathrm{mmol}$, and $0.852 \mathrm{~g}, 4 \mathrm{mmol}$ ), anhydrous iron(III) chlorides ( $1.63 \mathrm{~g}, 10 \mathrm{mmol} ; 1.63 \mathrm{~g}, 10 \mathrm{mmol}$, and $0.65 \mathrm{~g}, 4 \mathrm{mmol}$ ), and silver tribromoacetates (16.16 g, $40 \mathrm{mmol} ; 16.16 \mathrm{~g}, 40 \mathrm{mmol}$, and $6.46 \mathrm{~g}, 16 \mathrm{mmol}$ ), respectively, were mixed in stoichiometric amounts in nitromethane and stirred for 8 hours. Silver halide formed, respectively, were filtered under positive pressure of dry nitrogen and the corresponding filterate were evaporated to a very small volume. These were treated with dry diethylether and in each case jelly like mass was formed. The corresponding masses were evaporated to dryness under vacuum under the atmosphere of nitrogen. On analysis, the products formed were found $\mathrm{K}\left[\mathrm{Fe}\left(\mathrm{CBr}_{3} \mathrm{COO}\right)_{4}\right]$ (Yield $80 \%$ ), $\mathrm{Rb}\left[\mathrm{Fe}\left(\mathrm{CBr}_{3} \mathrm{COO}\right)_{4}\right]$ (Yield $\left.82 \%\right)$ and $\mathrm{Cs}\left[\mathrm{Fe}\left(\mathrm{CBr}_{3} \mathrm{COO}\right)_{4}\right]$ (Yield 81\%).

2.5. Preparation of Bis(Tetramethylammonium)Tetrachloro metallates(II), That Is, $\left(\mathrm{Me}_{4} \mathrm{~N}_{2} \mathrm{MCl}_{4}\right.$ Where $\mathrm{M}=\mathrm{Mn}$, Co, $\mathrm{Ni}, \mathrm{Cu}$. In a typical preparation, anhydrous metal chloride and tetramethylammonium chloride in $1: 2$ molar ratio were separately dissolved in absolute ethanol. On mixing the two solutions, a solid was precipitated out which was filtered and dried in vacuum. Amount, colour, yield, and elemental analysis of various products obtained are given in Table 1.

2.6. Preparation of Bis(Tetramethylammonium) Tetratribromoacetato Metallates(II) of $\mathrm{Mn}, \mathrm{Co}, \mathrm{Ni}$, and $\mathrm{Cu}$. These tribromoacetates were prepared by mixing the Bis(tetramethylammonium) tetrachloro metallates, that is, $\left[\mathrm{Me}_{4} \mathrm{~N}\right]_{2}\left[\mathrm{MnCl}_{4}\right] \quad(1.35 \mathrm{~g}) ; \quad\left[\mathrm{Me}_{4} \mathrm{~N}\right]_{2}\left[\mathrm{CoCl}_{4}\right] \quad(1.047 \mathrm{~g}) ;$ $\left[\mathrm{Me}_{4} \mathrm{~N}\right]_{2}\left[\mathrm{NiCl}_{4}\right](1.046 \mathrm{~g}) ;\left[\mathrm{Me}_{4} \mathrm{~N}\right]_{2}\left[\mathrm{CuCl}_{4}\right](1.061 \mathrm{~g})$, respectively, with silver tribromoacetate $(4.848 \mathrm{~g}, 12 \mathrm{mmol}$ in each case) in nitromethane in stoichiometric amounts. Silver chloride formed after stirring for 8 hours was filtered under dry nitrogen. Filterate was evaporated to dryness under nitrogen atmosphere. Product obtained were $\left[\mathrm{Me}_{4} \mathrm{~N}\right]_{2}\left[\mathrm{Mn}\left(\mathrm{O}_{2} \mathrm{CCBr}_{3}\right)_{4}\right]$ (light Green in colour, yield $84 \%$ ); $\left[\mathrm{Me}_{4} \mathrm{~N}\right]_{2}\left[\mathrm{Co}\left(\mathrm{O}_{2} \mathrm{CCBr}_{3}\right)_{4}\right]$ (pinkish violet in colour, yield $85 \%$ ); $\left[\mathrm{Me}_{4} \mathrm{~N}\right]_{2}\left[\mathrm{Ni}_{2}\left(\mathrm{O}_{2} \mathrm{CCBr}_{3}\right)_{4}\right]$ (green in colour, Yield $80 \%$ ); $\left[\mathrm{Me}_{4} \mathrm{~N}\right]_{2}\left[\mathrm{Cu}\left(\mathrm{O}_{2} \mathrm{CCBr}_{3}\right)_{4}\right]$ (bluish green in colour, yield $85 \%$ ).

\section{Results and Discussions}

Anhydrous iron(III) chloride $(3.25 \mathrm{~g}, 20 \mathrm{mmol})$ when refluxed with fused tribromoacetic acid $(11.88 \mathrm{~g}, 40 \mathrm{mmol})$ under nitrogen atmosphere with stirring for 9-10 hours, a yellow coloured solid compound separated out and it was filtered and washed with anhydrous dichloromethane and finally dried in vacuum. The elemental analysis corresponds to $\mathrm{Fe}_{2} \mathrm{Cl}_{2}\left[\mathrm{O}_{2} \mathrm{CCBr}_{3}\right]_{4}$. This compound $\mathrm{Fe}_{2} \mathrm{Cl}_{2}\left[\mathrm{O}_{2} \mathrm{CCBr}_{3}\right]_{4}$ $(6.837 \mathrm{~g}, 5 \mathrm{mmol})$ was refluxed with tribromoacetic acid $(1.1845 \mathrm{~g}, 5 \mathrm{mmol})$ in carbon tetrachloride for about 4 hours with stirring. A light pink solid separated out which was filtered and washed with anhydrous dichloromethane and finally dried under vacuum. The elemental analysis corresponds to $\mathrm{Fe}_{2} \mathrm{Cl}\left(\mathrm{O}_{2} \mathrm{CCBr}_{3}\right)_{5}$. This compound $\mathrm{Fe}_{2} \mathrm{Cl}\left(\mathrm{O}_{2} \mathrm{CCBr}_{3}\right)_{5} \quad(3.255 \mathrm{~g}, 2 \mathrm{mmol})$ was refluxed with excess tribromoacetic acid $(0.594 \mathrm{~g}, 2 \mathrm{mmol})$ in carbon tetrachloride till evolution of $\mathrm{HCl}$ gas ceased and whole 
TABle 2: Physical and analytical data, molar conductance, and magnetic moments of $\mathrm{Fe}_{2} \mathrm{Cl}_{2}\left(\mathrm{O}_{2} \mathrm{CCBr}_{3}\right)_{4}, \mathrm{Fe}_{2} \mathrm{Cl}\left(\mathrm{O}_{2} \mathrm{CCBr}\right)_{5}$, and $\mathrm{Fe}\left(\mathrm{O}_{2} \mathrm{CCBr}\right)_{3}$.

\begin{tabular}{|c|c|c|c|c|c|c|c|c|c|}
\hline \multirow{2}{*}{ Compound } & \multirow{2}{*}{ Colour } & \multicolumn{6}{|c|}{ Analysis (\%) found (calculated) } & \multirow{2}{*}{$\mu_{\text {eff. }}($ B.M.) } & \multirow{2}{*}{ Molar conductance $\mathrm{cm}^{2} \mathrm{ohm}^{-1} \mathrm{~mole}^{-1}$ in $\mathrm{CH}_{3} \mathrm{CN}$} \\
\hline & & M & $\mathrm{Br}$ & $\mathrm{Cl}$ & $\mathrm{C}$ & $\mathrm{H}$ & $\mathrm{N}$ & & \\
\hline $\mathrm{Fe}\left(\mathrm{O}_{2} \mathrm{CCBr}_{3}\right)_{3}$ & Orange red & $\begin{array}{c}5.86 \\
(5.92)\end{array}$ & $\begin{array}{c}75.78 \\
(76.28)\end{array}$ & - & $\begin{array}{c}7.42 \\
(7.63)\end{array}$ & - & - & 3.48 & 10.28 \\
\hline $\mathrm{Fe}_{2} \mathrm{Cl}_{2}\left(\mathrm{O}_{2} \mathrm{CCBr}_{3}\right)_{4}$ & Yellow & $\begin{array}{c}7.96 \\
(8.17)\end{array}$ & $\begin{array}{c}69.89 \\
(70.24)\end{array}$ & $\begin{array}{c}4.95 \\
(5.19)\end{array}$ & $\begin{array}{c}6.89 \\
(7.02)\end{array}$ & - & - & 4.52 & 46.82 \\
\hline $\mathrm{Fe}_{2} \mathrm{Cl}\left(\mathrm{O}_{2} \mathrm{CCBr}_{3}\right)_{5}$ & Light pink & $\begin{array}{c}6.67 \\
(6.86)\end{array}$ & $\begin{array}{c}72.15 \\
(73.74)\end{array}$ & $\begin{array}{c}2.15 \\
(2.18)\end{array}$ & $\begin{array}{c}7.15 \\
(7.37)\end{array}$ & - & - & 3.54 & 23.48 \\
\hline
\end{tabular}

TABLE 3: Infrared spectral bands $\left(\mathrm{cm}^{-1}\right)$ of $\mathrm{Fe}_{2} \mathrm{Cl}_{2}\left(\mathrm{O}_{2} \mathrm{CCBr}_{3}\right)_{4}, \mathrm{Fe}_{2} \mathrm{Cl}\left(\mathrm{O}_{2} \mathrm{CCBr}_{3}\right)_{5}$, and $\mathrm{Fe}\left(\mathrm{O}_{2} \mathrm{CCBr}\right)_{3}$.

\begin{tabular}{|c|c|c|c|}
\hline $\mathrm{Fe}_{2} \mathrm{Cl}_{2}\left(\mathrm{O}_{2} \mathrm{CCBr}_{3}\right)_{4}$ & $\mathrm{Fe}_{2} \mathrm{Cl}\left(\mathrm{O}_{2} \mathrm{CCBr}_{3}\right)_{5}$ & $\mathrm{Fe}\left(\mathrm{O}_{2} \mathrm{CCBr}\right)_{3}$ & Assignments \\
\hline $1655 \mathrm{~s}$ & $1635 \mathrm{~s}$ & 1680,1630 & COO asym.str. \\
\hline $1480 \mathrm{~m}$ & $1470 \mathrm{~m}$ & $1488 \mathrm{~s}$ & COO sym.str. \\
\hline $1200 \mathrm{~s}$ & $1195 \mathrm{~s}$ & $1205 \mathrm{~s}$ & $\mathrm{CBr}_{3}$ str. \\
\hline $1180 \mathrm{~m}$ & $1160 \mathrm{sh}$ & 1170 & $\mathrm{CBr}_{3}$ str. \\
\hline $860 \mathrm{~s}$ & $850 \mathrm{w}$ & 862 & $\mathrm{C}-\mathrm{C}$ str. \\
\hline $790 \mathrm{~s}$ & $790 \mathrm{~m}$ & $800 \mathrm{~s}$ & $\mathrm{O}-\mathrm{C}-\mathrm{O}$ deform. \\
\hline $730 \mathrm{~s}$ & $720 \mathrm{~s}$ & $742 \mathrm{~s}$ & $\mathrm{CBr}_{3}$ bend. \\
\hline $640 \mathrm{~s}$ & - & $670 w$ & - \\
\hline $630 \mathrm{~s}$ & $610 \mathrm{~s}$ & $645 \mathrm{w}$ & $\mathrm{CBr}_{3}$ bend. \\
\hline $520 \mathrm{~s}$ & $530 \mathrm{~m}$ & $545 \mathrm{w}$ & $\mathrm{CBr}_{3}$ bend. \\
\hline $475 \mathrm{~m}$ & $465 \mathrm{w}$ & 455 & $\mathrm{M}-\mathrm{O}$ \\
\hline $385 \mathrm{~m}$ & - & 480 & CCO bend. \\
\hline $325 \mathrm{~m}$ & - & - & $\mathrm{M}-\mathrm{Cl}$ \\
\hline $240 \mathrm{w}$ & - & $280 \mathrm{w}$ & $\mathrm{CBr}_{3}$ rock. \\
\hline
\end{tabular}

s: strong, m: medium, w: weak.

of the solid dissolved to give an orange coloured solution. This solution was evaporated to dryness. An orange red compound $\mathrm{Fe}\left(\mathrm{CCBr}_{3}\right)_{3}$ was obtained.

Both these compounds $\mathrm{Fe}_{2} \mathrm{Cl}_{2}\left(\mathrm{O}_{2} \mathrm{CCBr}_{3}\right)_{4}$ and $\mathrm{Fe}_{2} \mathrm{Cl}\left(\mathrm{O}_{2} \mathrm{CCBr}_{3}\right)_{5}$ are hygroscopic solids insoluble in common organic solvents but soluble in nitromethane and acetonitrile to give red coloured solution. It is difficult to assign particular molecular formula to these compound but they are expected to be higher polymer like other iron(III) carboxylates [15]. The dimeric formulation for $\mathrm{Fe}_{2} \mathrm{Cl}_{2}\left(\mathrm{O}_{2} \mathrm{CCBr}_{3}\right)_{4}$ is favoured in view of its reaction with fused tribromoacetic acid to give $\mathrm{Fe}_{2} \mathrm{Cl}\left(\mathrm{O}_{2} \mathrm{CCBr}_{3}\right)_{5}$. Molar conductance of millimolar solutions of $\mathrm{Fe}_{2} \mathrm{Cl}_{2}\left(\mathrm{O}_{2} \mathrm{CCBr}_{3}\right)_{4}$ and $\mathrm{Fe}_{2} \mathrm{Cl}\left(\mathrm{O}_{2} \mathrm{CCBr}_{3}\right)_{5}$ in nitromethane are 46.82 and 23.48 $\mathrm{ohm}^{-1} \mathrm{~cm}^{2} \mathrm{~mol}^{-1}$, respectively, ruled out their possibility of their ionic nature. The compound $\mathrm{Fe}\left(\mathrm{O}_{2} \mathrm{CCBr}_{3}\right)_{3}$ is found soluble in diethylether and acetonitrile. Molar conductance of its millimolar solution is $10.28 \mathrm{ohm}^{-1} \mathrm{~cm}^{2} \mathrm{~mol}^{-1}$ ruling out its ionic nature (Table 2).

Infrared spectra of $\mathrm{Fe}_{2} \mathrm{Cl}_{2}\left(\mathrm{O}_{2} \mathrm{CCBr}_{3}\right)_{4}$ and $\mathrm{Fe}_{2} \mathrm{Cl}\left(\mathrm{O}_{2} \mathrm{CCBr}_{3}\right)_{5}$ shows strong asymmetric and medium intensity symmetric stretching modes of tribromoacetic group at $1655 \mathrm{~cm}^{-1}, 1635 \mathrm{~cm}^{-1}$ and $1480 \mathrm{~cm}^{-1}, 1470 \mathrm{~cm}^{-1}$, respectively. $\Delta v_{\mathrm{COO}}$ of the order of $175 \mathrm{~cm}^{-1}$ and $165 \mathrm{~cm}^{-1}$ are comparable to those of many metal tribromoacetate complexes in which bridging tribromoacetate groups are anticipated.

Metal-chlorine stretching frequencies usually reported $[16,17]$ in the range $225-375 \mathrm{~cm}^{-1}$. For tetrahedral $\mathrm{FeCl}_{4}^{-}$ anion, $v_{\mathrm{Fe}-\mathrm{Cl}}$ was observed at $378 \mathrm{~cm}^{-1}$. This frequency is expected to shift progressively to lower frequency as the coordination number of metal increases from 4 to 6 . Although the trend may be confused by the effect of steric interactions, double bondings and differences in a d-subshell population [18]. In $\mathrm{Fe}_{2} \mathrm{Cl}_{2}\left(\mathrm{O}_{2} \mathrm{CCBr}_{3}\right)_{4}$, the medium intensity band at $325 \mathrm{~cm}^{-1}$ is assigned to $\mathrm{Fe}-\mathrm{Cl}$ stretching mode. In case of $\mathrm{Fe}_{2} \mathrm{Cl}\left(\mathrm{O}_{2} \mathrm{CCBr}_{3}\right)_{5}$ this band could not be assigned due to poorly resolved spectrum observed in the lower region.

Similar infrared spectra was observed for $\mathrm{Fe}\left(\mathrm{O}_{2} \mathrm{CCBr}\right)_{3}$ what one obtained from the reaction of $\mathrm{Fe}_{2} \mathrm{Cl}\left(\mathrm{O}_{2} \mathrm{CCBr}_{3}\right)_{5}$ with fused tribromoacetic acid and also by metathetical reactions of ferric chloride with silver tribromoacetate. The magnitude of $v_{\text {asym COO }}$ band in $\mathrm{Fe}\left(\mathrm{O}_{2} \mathrm{CCBr}_{3}\right)_{3}$ indicate the presence of unidentate and bidentate bridging tribromoacetate groups. Some important assignments are given in Table 3.

The ultraviolet and visible reflectance spectrum of $\mathrm{Fe}\left(\mathrm{O}_{2} \mathrm{CCBr}_{3}\right)_{3}$ have been reported and assignments have been made on the basis of octahedral environment around the metal atom. The diffused reflectance spectra of $\mathrm{Fe}_{2} \mathrm{Cl}_{2}\left(\mathrm{O}_{2} \mathrm{CCBr}_{3}\right)_{4}, \mathrm{Fe}_{2} \mathrm{Cl}\left(\mathrm{O}_{2} \mathrm{CCBr}_{3}\right)_{5}$ and $\mathrm{Fe}\left(\mathrm{O}_{2} \mathrm{CCBr}_{3}\right)_{3}$ in 
TABLE 4: Diffused reflectance spectra $\left(\mathrm{cm}^{-1}\right)$ of $\mathrm{Fe}_{2} \mathrm{Cl}_{2}\left(\mathrm{O}_{2} \mathrm{CCBr}\right)_{4}, \mathrm{Fe}_{2} \mathrm{Cl}\left(\mathrm{O}_{2} \mathrm{CCBr}_{3}\right)_{5}$, and $\mathrm{Fe}\left(\mathrm{O}_{2} \mathrm{CCBr}\right)_{3}$.

\begin{tabular}{lccr}
\hline $\mathrm{Fe}_{2} \mathrm{Cl}_{2}\left(\mathrm{O}_{2} \mathrm{CCBr}_{3}\right)_{4}$ & $\mathrm{Fe}_{2} \mathrm{Cl}\left(\mathrm{O}_{2} \mathrm{CCBr}_{3}\right)_{5}$ & $\mathrm{Fe}\left(\mathrm{O}_{2} \mathrm{CCBr}\right)_{3}$ & \multicolumn{1}{c}{ Assignments } \\
\hline $495 \mathrm{Sh}$ & 460 & 519 & ${ }^{6} \mathrm{~A}_{1 \mathrm{~g}}$ to ${ }^{4} \mathrm{~A}_{1 \mathrm{~g}}(\mathrm{G})$ \\
938 & 923 & 942 & ${ }^{6} \mathrm{~A}_{1 \mathrm{~g}}$ to ${ }^{4} \mathrm{~T}_{1 \mathrm{~g}}(\mathrm{G})$ \\
- & - & 347 & Charge transfer \\
\hline
\end{tabular}

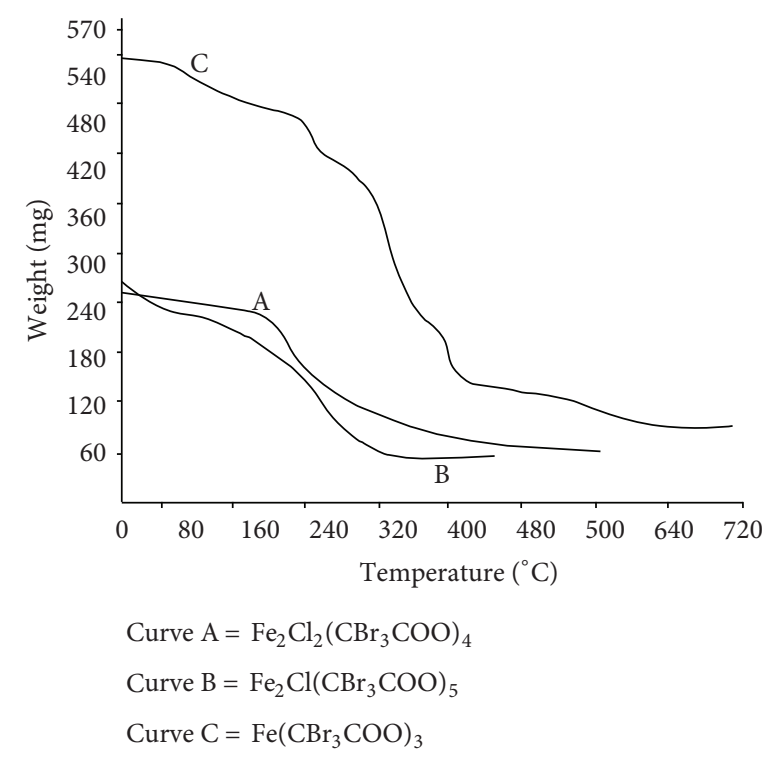

Figure 1: Thermogravimetric curves of $\mathrm{Fe}_{2} \mathrm{Cl}_{2}\left(\mathrm{O}_{2} \mathrm{CCBr}_{3}\right)_{4}, \mathrm{Fe}_{2} \mathrm{Cl}\left(\mathrm{O}_{2} \mathrm{CCBr}_{3}\right)_{5}$, and $\mathrm{Fe}\left(\mathrm{O}_{2} \mathrm{CCBr}\right)_{3}$.

the range $200-2000 \mathrm{~cm}^{-1}$ are given in Table 4 along with the tentative assignments.

Magnetic susceptibility measurement studies of these compounds have also been made to throw more light on the nature of these compounds. In an octahedral ligand field $\mathrm{d}^{5}$ configuration can give rise to compounds of either high spin $(S=5 / 2)$ or low spin $(S=1 / 2)$ types [19]. Highspin compounds are expected to possess magnetic moment value very close to spin only value of 5.92 B.M. and to be independent of temperature as the ground term is ${ }^{6} \mathrm{~A}_{1 \mathrm{~g}}$. The low spin compound gives rise to ${ }^{2} \mathrm{~T}_{2 g}$ and the temperature dependence of magnetic moment is a function of spin-orbit coupling parameter, that is, $\lambda=-460 \mathrm{~cm}^{-1}$. This value of wavelength leads to a magnetic moment of 2.4 B.M. which falls with temperature to approach 1.73 B.M. at $0 \mathrm{~K}$. Tetrahedral complexes also leads to ${ }^{6} \mathrm{~A}_{1 \mathrm{~g}}$ ground term and for them the magnetic moments are also anticipated to be near 5.92 B.M. and to be independent of temperature.

These compounds $\mathrm{Fe}_{2} \mathrm{Cl}_{2}\left(\mathrm{O}_{2} \mathrm{CCBr}_{3}\right)_{4}, \mathrm{Fe}_{2} \mathrm{Cl}\left(\mathrm{O}_{2} \mathrm{CCBr}_{3}\right)_{5}$ and $\mathrm{Fe}\left(\mathrm{O}_{2} \mathrm{CCBr}_{3}\right)_{3}$ are paramagnetic having magnetic moment 4.52, 3.54 and 3.48 B.M., respectively, at room temperature. These values are significantly lower from spin only value of 5.9 B.M. which is experimentally observed for iron(III) complexes [19]. These low values suggest that like many other iron(III) carboxylates, these tribromoacetates show some antiferromagnetic coupling between iron atoms [20].

Thermogravimetric studies have also been carried out on these complexes. T.G. curves for tribromoacetate are produced in the present discussion. DTG and DTA curve have been omitted. DTG minima have been used to locate clearly various inflection points on TG curves so that the weight changes belongs to every step are determined with greater accuracy.

The curve for $\mathrm{Fe}_{2} \mathrm{Cl}_{2}\left(\mathrm{O}_{2} \mathrm{CCBr}_{3}\right)_{4}, \mathrm{Fe}_{2} \mathrm{Cl}\left(\mathrm{O}_{2} \mathrm{CCBr}_{3}\right)_{5}$ (Curve A and $\mathrm{B}$, respectively, in Figure 1) show that thermal decomposition of these complexes consists of two steps as indicated by DTG curve and those two steps overlap and exact temperature at which first step is complete could not be determined. These compounds starts decomposing at $40^{\circ} \mathrm{C}$ and formation of final residue $\mathrm{Fe}_{2} \mathrm{O}_{3}$ is complete at $400^{\circ} \mathrm{C}$. The total weight loss in each case is in agreement with the value calculated on the basis of their proposed formula. (Weight loss for $\mathrm{Fe}_{2} \mathrm{Cl}_{2}\left(\mathrm{O}_{2} \mathrm{CCBr}_{3}\right)_{4}$, observed: $87.70 \%$; calc: 88.30\%; weight loss for $\mathrm{Fe}_{2} \mathrm{Cl}\left(\mathrm{O}_{2} \mathrm{CCBr}_{3}\right)_{5}$, observed: $89.40 \%$; calc: $90.17 \%)$. These two compounds were heated in vacuum at about $150^{\circ} \mathrm{C}$ and volatiles were trapped and identified as $\mathrm{CCBr}_{3} \mathrm{COCl}$ and $\left(\mathrm{CBr}_{3} \mathrm{CO}\right)_{2} \mathrm{O}$. Tribromoacetic anhydride was characterized from infra red spectrum ( $\nu_{\text {asym COO }} 1875$, 
TABLE 5: Infrared spectral bands $\left(\mathrm{cm}^{-1}\right)$ of $\mathrm{M}\left[\mathrm{Fe}\left(\mathrm{CBr}_{3} \mathrm{COO}\right)_{4}\right]$, where $\mathrm{M}=\mathrm{Me}_{4} \mathrm{~N}^{+}, \mathrm{K}^{+}, \mathrm{Rb}^{+}$and $\mathrm{Cs}^{+}$.

\begin{tabular}{|c|c|c|c|c|}
\hline$\left[\mathrm{Me}_{4} \mathrm{~N}\right]\left[\mathrm{Fe}\left(\mathrm{CBr}_{3} \mathrm{COO}\right)_{4}\right]$ & $\mathrm{K}\left[\mathrm{Fe}\left(\mathrm{CBr}_{3} \mathrm{COO}\right)_{4}\right]$ & $\mathrm{Rb}\left[\mathrm{Fe}\left(\mathrm{CBr}_{3} \mathrm{COO}\right)_{4}\right]$ & $\mathrm{Cs}\left[\mathrm{Fe}\left(\mathrm{CBr}_{3} \mathrm{COO}\right)_{4}\right]$ & Assignments \\
\hline $1650 \mathrm{sh}$ & $1700 \mathrm{sh}$ & $1680 \mathrm{~s}$ & $1670 \mathrm{sh}$ & \multirow{2}{*}{ COO asym.str. } \\
\hline $1580 \mathrm{~s}$ & $1655 \mathrm{~s}$ & $1655 \mathrm{~s}$ & $1655 \mathrm{~s}$ & \\
\hline $1475 \mathrm{sh}$ & 1410 & 1410 & $1440 \mathrm{sh}$ & \multirow{2}{*}{ COO sym.str. } \\
\hline $1400 \mathrm{sh}$ & $1400 \mathrm{sh}$ & $1400 \mathrm{sh}$ & $1420 \mathrm{sh}$ & \\
\hline $1200 \mathrm{~b}$ & 1205 & $1200 \mathrm{~m}$ & $1195 \mathrm{sh}$ & $\mathrm{CBr}_{3}$ str. \\
\hline $1150 \mathrm{~b}$ & $1150 \mathrm{~m}$ & $1150 \mathrm{~m}$ & $1150 \mathrm{~m}$ & \multirow{2}{*}{$\mathrm{CBr}_{3}$ str. } \\
\hline $885 \mathrm{vw}$ & $890 \mathrm{vw}$ & $895 \mathrm{vw}$ & - & \\
\hline $830 \mathrm{~s}$ & $850 \mathrm{~s}$ & $845 \mathrm{~s}$ & $850 \mathrm{~s}$ & \multirow{3}{*}{$\mathrm{C}-\mathrm{C}$ str. } \\
\hline $840 \mathrm{~s}$ & - & - & $840 \mathrm{~s}$ & \\
\hline $785 \mathrm{~s}$ & $785 \mathrm{~s}$ & $785 \mathrm{~s}$ & $790 \mathrm{~s}$ & \\
\hline $720 \mathrm{~s}$ & $720 \mathrm{~s}$ & $720 \mathrm{~s}$ & $720 \mathrm{~s}$ & OCO deform \\
\hline $655 \mathrm{w}$ & $655 \mathrm{w}$ & $650 \mathrm{w}$ & $660 \mathrm{w}$ & $\mathrm{CBr}_{3}$ bend \\
\hline $595 \mathrm{~s}$ & $595 \mathrm{~s}$ & $595 \mathrm{w}$ & $595 \mathrm{w}$ & $\mathrm{CBr}_{3}$ bend \\
\hline $510 \mathrm{~s}$ & $510 \mathrm{~s}$ & 520 & $510 \mathrm{w}$ & $\mathrm{CBr}_{3}$ bend \\
\hline $470 \mathrm{~s}$ & $465 \mathrm{sh}$ & $470 \mathrm{~s}$ & $475 \mathrm{~s}$ & $\mathrm{CBr}_{3}$ bend \\
\hline $370 \mathrm{w}$ & $370 \mathrm{w}$ & $365 \mathrm{w}$ & $370 \mathrm{w}$ & $\mathrm{M}-\mathrm{O}$ \\
\hline $1475 \mathrm{~s}$ & - & - & - & \multirow{2}{*}{ Band due to $\mathrm{Me}_{4} \mathrm{~N}$} \\
\hline $945 \mathrm{~s}$ & - & - & - & \\
\hline
\end{tabular}

sh: shoulder, b: broad, m: medium, v: sharp, w: weak, vw: very weak.

$1815 \mathrm{~cm}^{-1}$ ). Thus overall thermal decomposition may be proposed as:

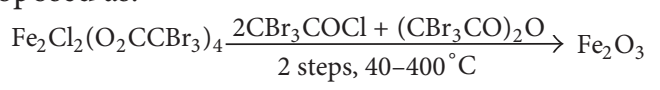

$$
\begin{aligned}
& 2 \mathrm{Fe}\left(\mathrm{O}_{2} \mathrm{CCBr}_{3}\right)_{3} \stackrel{-1 / 2\left(\mathrm{CBr}_{3} \mathrm{CO}\right)_{2} \mathrm{O}}{75-235^{\circ} \mathrm{C}} \mathrm{Fe}_{2} \mathrm{O}\left(\mathrm{O}_{2} \mathrm{CCBr}_{3}\right)_{4} \cdot 1 / 2\left(\mathrm{CBr}_{3} \mathrm{CO}\right)_{2} \mathrm{O} \\
& \left.-1 / 2\left(\mathrm{CBr}_{3} \mathrm{CO}\right)_{2} \mathrm{O}\right\rfloor 235-305^{\circ} \mathrm{C}
\end{aligned}
$$

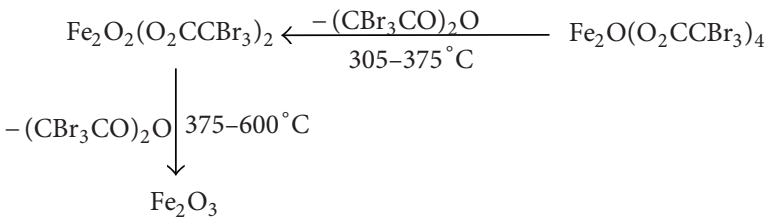

Tribromoacetic anhydride was obtained in good yield on heating $\mathrm{Fe}\left(\mathrm{O}_{2} \mathrm{CCBr}_{3}\right)_{3}$ in vacuum above $200^{\circ} \mathrm{C}$ and trapping the gaseous products.

TG curve $\mathrm{C}$ for $\mathrm{Fe}\left(\mathrm{O}_{2} \mathrm{CCBr}_{3}\right)_{3}$ in Figure 1 shows that decomposition consists of several steps. DTG minima have been projected on TG curve to get inflection point marked by small arrows on curve. The compound starts decomposing at $75^{\circ} \mathrm{C}$. The weight loss up to $235^{\circ} \mathrm{C}$ corresponds to one half molecule of $\left(\mathrm{CBr}_{3} \mathrm{CO}\right)_{2} \mathrm{O}$, if we start with two molecule of $\mathrm{Fe}\left(\mathrm{O}_{2} \mathrm{CCBr}_{3}\right)_{3}$ (weight loss, observed: $14.42 \%$, calc: $15.25 \%$ ). From 235 to $305^{\circ} \mathrm{C}$ another half molecule of tribromoacetic anhydride is lost. (weight loss observed: $29.80 \%$, calc: $30.50 \%$ ). Two molecules of tribromoacetic anhydride are lost between $305-600^{\circ} \mathrm{C}$ in two steps, one followed immediately by the other. (weight loss observed: 90.15\%, calc: $91.525 \%)$.
The compound $\left[\mathrm{Me}_{4} \mathrm{~N}\right]\left[\mathrm{Fe}\left(\mathrm{CBr}_{3} \mathrm{COO}\right)_{4}\right]$ has been prepared by metathetical reaction of $\left[\mathrm{Me}_{4} \mathrm{~N}\right]\left[\mathrm{FeCl}_{4}\right]$ with silver tribromoacetate in 1:4 molar ratio using nitromethane as solvent. The resulting solution was evaporated to dryness. Solid obtained was kept in diethylether and stirred for four hours and finally the solid mass was filtered under dry nitrogen atmosphere. The composition of compound was confirmed by elemental analysis. This is a dark red coloured compound insoluble in common organic solvents but soluble in nitromethane and acetonitrile. On the basis of insolubility in organic solvents, the compound is believed to be polymeric in nature. The molar conductance of its millimolar solution in nitromethane shows it to be $1: 1$ electrolyte.

Infrared spectrum of this compound has been studied in the range $2000-200 \mathrm{~cm}^{-1}$ (Table 5). The bands at 1650 and $1580 \mathrm{~cm}^{-1}$ have been assigned as $v_{\text {asym COO }}$ and bands at 1475 and $1400 \mathrm{~cm}^{-1}$ due to $v_{\text {sym CoO}}$. The splitting of both these carboxylate stretching frequency clearly indicate that unidentate tribromoacetato group is present in addition to bidentate bridging group. The magnitude of the values of $\Delta v_{\mathrm{COO}}$ of 175 and $180 \mathrm{~cm}^{-1}$ indicate unidentate and bidentate bridging group. The bands at 1470 and $945 \mathrm{~cm}^{-1}$ are due to tetramethyl ammonium part of the compound. Other assignment have been made in a manner to analogous to compound reported in literature [21]. The room temperature magnetic moment for $\left[\mathrm{Me}_{4} \mathrm{~N}\right]\left[\mathrm{Fe}\left(\mathrm{CBr}_{3} \mathrm{COO}\right)_{4}\right]$ has been observed as 2.19 B.M. and this shows that it is a low spin iron complex.

Anhydrous iron(III) chloride when refluxed with tribromoacetic acid in presence of anhydrous $\mathrm{KCl}$ in the required stoichiometric ratio in nitromethane as solvent for about 20 hours under dry nitrogen atmosphere. A red coloured 
TABLE 6: Amount, color, analysis, magnetic moments and molar conductance of $\mathrm{M}\left[\mathrm{Fe}\left(\mathrm{CBr}_{3} \mathrm{COO}\right)_{4}\right]$, where $\mathrm{M}=\mathrm{Me}_{4} \mathrm{~N}^{+}, \mathrm{K}^{+}, \mathrm{Rb}^{+}$and $\mathrm{Cs}{ }^{+}$.

\begin{tabular}{|c|c|c|c|c|c|c|c|c|c|}
\hline \multirow{2}{*}{ Compound } & \multirow{2}{*}{ Colour } & \multicolumn{6}{|c|}{ Analysis (\%) found (calculated) } & \multirow[t]{2}{*}{$\mu_{\text {eff. }}$ (B.M.) } & \multirow{2}{*}{$\begin{array}{c}\text { Molar conductance } \\
\mathrm{cm}^{2} \mathrm{ohm}^{-1} \mathrm{~mole}^{-1} \text { in } \mathrm{CH}_{3} \mathrm{CN}\end{array}$} \\
\hline & & $\mathrm{Fe}$ & M & $\mathrm{Br}$ & $\mathrm{C}$ & $\mathrm{H}$ & $\mathrm{N}$ & & \\
\hline$\left[\mathrm{Me}_{4} \mathrm{~N}\right]\left[\mathrm{Fe}\left(\mathrm{CBr}_{3} \mathrm{COO}\right)_{4}\right]$ & Dark red & $\begin{array}{c}4.16 \\
(4.25)\end{array}$ & - & $\begin{array}{c}71.90 \\
(73.06)\end{array}$ & $\begin{array}{c}10.55 \\
(10.95)\end{array}$ & $\begin{array}{c}0.85 \\
(0.91)\end{array}$ & $\begin{array}{c}1.00 \\
(1.065)\end{array}$ & 2.19 & 99.7 \\
\hline $\mathrm{K}\left[\mathrm{Fe}\left(\mathrm{CBr}_{3} \mathrm{COO}\right)_{4}\right]$ & Red & $\begin{array}{c}4.21 \\
(4.37)\end{array}$ & $\begin{array}{c}3.00 \\
(3.05)\end{array}$ & $\begin{array}{c}74.40 \\
(75.05)\end{array}$ & $\begin{array}{c}7.35 \\
(7.51)\end{array}$ & - & - & 2.47 & 85.2 \\
\hline $\mathrm{Rb}\left[\mathrm{Fe}\left(\mathrm{CBr}_{3} \mathrm{COO}\right)_{4}\right]$ & Red & $\begin{array}{c}4.10 \\
(4.22)\end{array}$ & $\begin{array}{c}6.32 \\
(6.52)\end{array}$ & $\begin{array}{c}71.80 \\
(72.43)\end{array}$ & $\begin{array}{c}6.99 \\
(7.25)\end{array}$ & - & - & 2.43 & 80.4 \\
\hline $\mathrm{Cs}\left[\mathrm{Fe}\left(\mathrm{CBr}_{3} \mathrm{COO}\right)_{4}\right]$ & Red & $\begin{array}{c}3.95 \\
(4.07)\end{array}$ & $\begin{array}{c}9.35 \\
(9.67)\end{array}$ & $\begin{array}{c}68.70 \\
(69.90)\end{array}$ & $\begin{array}{c}6.65 \\
(6.99)\end{array}$ & - & - & 2.15 & 84.6 \\
\hline
\end{tabular}

TABle 7: Physical and analytical data of $\left[\left(\mathrm{Me}_{4} \mathrm{~N}\right)_{2}\right]\left[\mathrm{M}\left(\mathrm{CBr}_{3} \mathrm{COO}\right)_{4}\right]$, where $\mathrm{M}=\mathrm{Co}(\mathrm{II}), \mathrm{Ni}(\mathrm{II}), \mathrm{Mn}(\mathrm{II})$, and $\mathrm{Cu}(\mathrm{II})$.

\begin{tabular}{|c|c|c|c|c|c|c|c|}
\hline \multirow{2}{*}{ Compound } & \multirow{2}{*}{ Colour } & \multicolumn{5}{|c|}{ Analysis (\%) found (calculated) } & \multirow{2}{*}{$\mu_{\text {eff. }}(\mathrm{BM})$} \\
\hline & & M & $\mathrm{Br}$ & $\mathrm{C}$ & $\mathrm{H}$ & $\mathrm{N}$ & \\
\hline$\left[\left(\mathrm{Me}_{4} \mathrm{~N}\right)_{2}\right]\left[\mathrm{Co}\left(\mathrm{CBr}_{3} \mathrm{COO}\right)_{4}\right]$ & Violet pink & $4.15(4.23)$ & $67.85(69.02)$ & $13.52(13.80)$ & $1.68(1.72)$ & $1.90(2.01)$ & 4.27 \\
\hline$\left[\left(\mathrm{Me}_{4} \mathrm{~N}\right)_{2}\right]\left[\mathrm{Ni}\left(\mathrm{CBr}_{3} \mathrm{COO}\right)_{4}\right]$ & Green & $4.15(4.22)$ & $67.85(69.03)$ & $13.45(13.80)$ & $1.70(1.72)$ & $1.95(2.01)$ & 3.28 \\
\hline$\left[\left(\mathrm{Me}_{4} \mathrm{~N}\right)_{2}\right]\left[\mathrm{Mn}\left(\mathrm{CBr}_{3} \mathrm{COO}\right)_{4}\right]$ & Pink & $3.89(3.96)$ & $67.65(69.22)$ & $13.59(13.84)$ & $1.70(1.73)$ & $1.98(2.02)$ & 6.15 \\
\hline$\left[\left(\mathrm{Me}_{4} \mathrm{~N}\right)_{2}\right]\left[\mathrm{Cu}\left(\mathrm{CBr}_{3} \mathrm{COO}\right)_{4}\right]$ & Bluish green & $4.40(4.55)$ & $66.80(68.79)$ & $13.48(13.75)$ & $1.69(1.72)$ & $1.96(2.01)$ & 2.00 \\
\hline
\end{tabular}

solution is obtained. This red coloured solution on evaporation to a small volume, red coloured sticky mass was formed, and this mass was dissolved in diethylether and this was evaporated to dryness in vacuum. The elemental analysis of this compound corresponds to $\mathrm{K}\left[\mathrm{Fe}\left(\mathrm{CBr}_{3} \mathrm{COO}\right)_{4}\right]$ as shown in Table 6.

In a typical preparation alkali metal halide, anhydrous iron(III) chloride, and silver tribromo acetate were mixed in stoichiometric ratio in nitromethane and stirred for four hours. Silver halide was filtered under positive pressure of dry nitrogen and filterate was evaporated to a very small volume and this was treated with diethylether. A jelly like mass was formed. This mass was evaporated to dryness. All these compounds are red in colour, extremely hygroscopic solid which are insoluble in nonpolar organic solvents but soluble in acetonitrile and nitromethane. Molar conductance value of their millimolar solutions of $\mathrm{K}\left[\mathrm{Fe}\left(\mathrm{O}_{2} \mathrm{CCBr}_{3}\right)_{4}\right], \mathrm{Rb}\left[\mathrm{Fe}\left(\mathrm{O}_{2} \mathrm{CCBr}_{3}\right)_{4}\right]$, and $\mathrm{Cs}\left[\mathrm{Fe}\left(\mathrm{O}_{2} \mathrm{CCBr}_{3}\right)_{4}\right]$ indicate them to be $1: 1$ electrolyte in nitromethane as expected from empirical formula of these complexes. An interesting observation regarding these complexes is that unlike $\left[\mathrm{Me}_{4} \mathrm{~N}\right]\left[\mathrm{Fe}\left(\mathrm{O}_{2} \mathrm{CCBr}_{3}\right)_{4}\right]$ these compounds form jelly like solid when these compounds dissolved in diethylether and that may be attributed to their polymeric structure with large interstitial space in polymeric layer and solvent molecule get embedded in those spaces.

Infrared spectra of these compounds have been recorded in range $2000-200 \mathrm{~cm}^{-1}$ (Table 5). The higher frequency band at 1670,1680 , and $1700 \mathrm{~cm}^{-1}$ in cesium, rubidium and potassium complexes, respectively, may be assigned

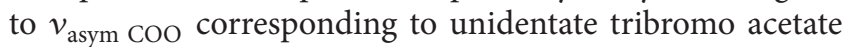
group whereas band at $1655 \mathrm{~cm}^{-1}$ in all these compounds indicate the presence of bidentate bridging groups.
Metathetical reactions of $\left[\mathrm{Me}_{4} \mathrm{~N}\right]_{2}\left[\mathrm{MCl}_{4}\right]$ with silver tribromoacetate in nitromethane yield solution of corresponding tribromoacetate. This solution on evaporation to dryness gives the corresponding tribromoacetate complex as shown in Table 7. These complexes are hygroscopic solid, soluble in polar organic solvents acetonitrile and nitromethane but insoluble in non polar organic solvents. The reaction of $\left[\mathrm{Me}_{4} \mathrm{~N}\right]_{2}\left[\mathrm{MCl}_{4}\right]$ with tribromoacetic acid do not give completely substituted product and the metathetical reaction in absolute ethanol are not promising. The molar conductance value of millimolar solution in acetonitrile, that is, $250 \mathrm{ohm}^{-1} \mathrm{~cm}^{2} \mathrm{~mole}^{-1}$ are well in the range expected for ionic formulation.

The infrared spectra of the compound have been recorded in the range $2000-200 \mathrm{~cm}^{-1}$ (Table 8). The characteristics feature of the spectra are appearance of $v_{\text {asymm COO at }}$ $1680 \mathrm{~cm}^{-1}$. The band around $1430 \mathrm{~cm}^{-1}$ has been assigned as $v_{\text {symm COO }}$. The $\Delta v_{\mathrm{COO}}$ values of $250 \mathrm{~cm}^{-1}$ compare well with that of $271 \mathrm{~cm}^{-1}$ reported for analogous compound [22]. Strong band around 1490 and $950 \mathrm{~cm}^{-1}$ are assigned to tetramethylammonium group.

The electronic spectra in the octahedral field energy level diagram for $\mathrm{Mn}$ (II) ( $\mathrm{d}^{5}$ configuration) is same as tetrahedral field energy level sequence. It follows that same energy level diagram may be used for tetrahedral, octahedral, and cubic field. In octahedral field, this configuration gives spin forbidden as well as parity forbidden transitions and thus extremely pale yellow coloured compound were observed [23]. In tetrahedral environment, the transitions are still spin forbidden but no longer parity forbidden. The compound having light green colour and very weak band at 325, 415, 565 , and $695 \mathrm{~cm}^{-1}$ in diffused reflectance spectra of Manganese complex favour a tetrahedral environment around 
TABLE 8: Infrared Spectral Bands $\left(\mathrm{cm}^{-1}\right)$ of $\left[\left(\mathrm{Me}_{4} \mathrm{~N}\right)_{2}\right]\left[\mathrm{M}\left(\mathrm{CBr}_{3} \mathrm{COO}\right)_{4}\right]$, where $\mathrm{M}=\mathrm{Co}(\mathrm{II}), \mathrm{Ni}(\mathrm{II}), \mathrm{Mn}(\mathrm{II})$, and $\mathrm{Cu}(\mathrm{II})$.

\begin{tabular}{|c|c|c|c|c|}
\hline $\begin{array}{l}{\left[\left(\mathrm{Me}_{4} \mathrm{~N}\right)_{2}\right]} \\
{\left[\mathrm{Mn}\left(\mathrm{CBr}_{3} \mathrm{COO}\right)_{4}\right]}\end{array}$ & $\begin{array}{c}{\left[\left(\mathrm{Me}_{4} \mathrm{~N}\right)_{2}\right]} \\
{\left[\mathrm{Co}\left(\mathrm{CBr}_{3} \mathrm{COO}\right)_{4}\right]}\end{array}$ & $\begin{array}{c}{\left[\left(\mathrm{Me}_{4} \mathrm{~N}\right)_{2}\right]} \\
{\left[\mathrm{Ni}\left(\mathrm{CBr}_{3} \mathrm{COO}\right)_{4}\right]}\end{array}$ & $\begin{array}{c}{\left[\left(\mathrm{Me}_{4} \mathrm{~N}\right)_{2}\right]} \\
{\left[\mathrm{Cu}\left(\mathrm{CBr}_{3} \mathrm{COO}\right)_{4}\right]}\end{array}$ & Assignments \\
\hline $1685 \mathrm{~s}$ & $1680 \mathrm{~s}$ & $1680 s$ & $1685 \mathrm{~s}$ & COO asym. Str. \\
\hline $1425 \mathrm{~m}$ & $1420 \mathrm{~s}$ & $1420 \mathrm{~s}$ & $1425 \mathrm{~m}$ & COO sym. Str. \\
\hline $1190 \mathrm{~m}$ & $1195 \mathrm{~s}$ & $1200 \mathrm{~s}$ & $1205 \mathrm{~m}$ & $\mathrm{CBr}_{3}$ str. \\
\hline $1160 \mathrm{vw}$ & $1165 \mathrm{sh}$ & $1170 \mathrm{sh}$ & $1170 \mathrm{w}$ & $\mathrm{CBr}_{3}$ str. \\
\hline $1100 \mathrm{w}$ & $1105 \mathrm{~m}$ & 1105 & $1170 \mathrm{w}$ & $\mathrm{CBr}_{3}$ str. \\
\hline $1490 \mathrm{~s}$ & $1485 \mathrm{~s}$ & $1488 \mathrm{~s}$ & $1485 \mathrm{~s}$ & Band due to \\
\hline $945 \mathrm{~s}$ & $945 \mathrm{~s}$ & $950 \mathrm{~s}$ & $945 \mathrm{~s}$ & $\mathrm{Me}_{4} \mathrm{~N}^{+}$group \\
\hline $835 \mathrm{~s}$ & $830 \mathrm{~m}$ & $830 \mathrm{~s}$ & $835 \mathrm{~s}$ & \multirow{2}{*}{ C-C str. } \\
\hline $800 \mathrm{~s}$ & $795 \mathrm{~s}$ & $800 \mathrm{~s}$ & $975 \mathrm{~s}$ & \\
\hline $725 \mathrm{~s}$ & $725 \mathrm{~s}$ & $725 \mathrm{~s}$ & $730 \mathrm{~s}$ & OCO deform. \\
\hline $630 \mathrm{~s}$ & - & $630 \mathrm{w}$ & $630 \mathrm{~s}$ & $\mathrm{CBr}_{3}$ bend \\
\hline $540 \mathrm{vw}$ & $535 \mathrm{w}$ & - & $545 \mathrm{vw}$ & $\mathrm{CBr}_{3}$ bend \\
\hline $465 \mathrm{vw}$ & $460 \mathrm{~m}$ & $465 \mathrm{w}$ & $470 \mathrm{w}$ & $\mathrm{M}-\mathrm{O}$ \\
\hline $265 \mathrm{~m}$ & $270 \mathrm{~m}$ & $270 \mathrm{~m}$ & $270 \mathrm{~m}$ & $\mathrm{CBr}_{3}$ Wag. \\
\hline
\end{tabular}

$3\left[\mathrm{Me}_{4} \mathrm{~N}\right]_{2}\left[\mathrm{Mn}\left(\mathrm{O}_{2} \mathrm{CCBr}_{3}\right)_{4}\right] \stackrel{6\left(\mathrm{CBr}_{3} \mathrm{CO}\right)_{2} \mathrm{O}+\text { combustible material }}{45-390^{\circ} \mathrm{C}} \mathrm{Mn}_{3} \mathrm{O}_{4}$

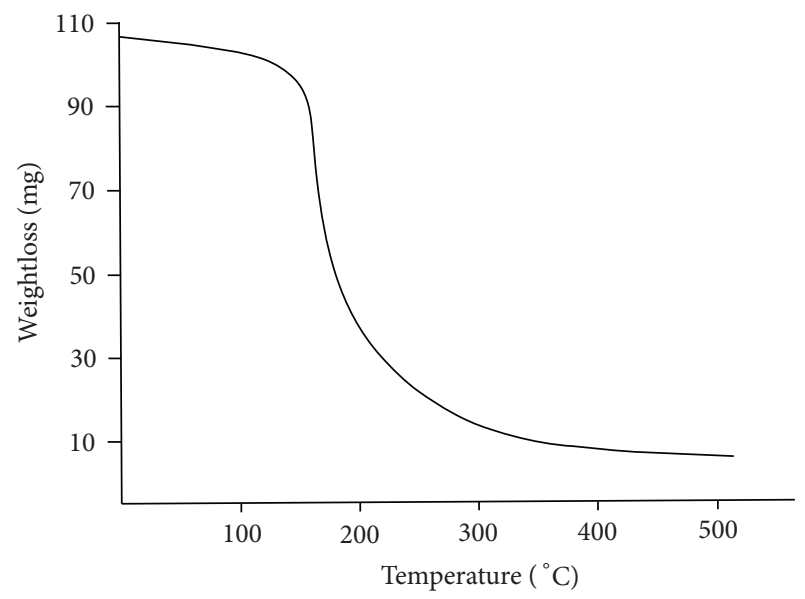

Figure 2: Thermogravimetric curves of $\left[\mathrm{Me}_{4} \mathrm{~N}\right]_{2}\left[\mathrm{Mn}\left(\mathrm{CBr}_{3} \mathrm{Coo}\right)_{4}\right]$.

manganese atom. These bands are similar to other tetrahedral $\mathrm{Mn}$ (II) complexes [24]. The band at $250 \mathrm{~cm}^{-1}$ is assigned to charge transfer band.

In the spectra of tetrahedral cobalt(II) derivatives $v_{2}$ $\left[{ }^{4} \mathrm{~A}_{2} \rightarrow{ }^{4} \mathrm{~T}_{1}(\mathrm{~F})\right]$ and $v_{3}\left[{ }^{4} \mathrm{~A}_{2} \rightarrow{ }^{4} \mathrm{~T}_{1}(\mathrm{P})\right]$ transitions appear as multiple absorption in the near infrared and visible regions, respectively [25]. The assignment in the diffused reflectance spectrum of cobalt(II) have been observed by comparing it with spectra of several other tetrahedral cobalt(II) complexes in which ligands are bonded through oxygen such as Co $\left[\left(\mathrm{C}_{6} \mathrm{H}_{5}\right)_{3} \mathrm{PO}\right]_{4}{ }^{2+}$ ion [26] and $\mathrm{Co}\left[\left(\mathrm{Me}_{2} \mathrm{~N}\right)_{2} \mathrm{PO}_{4}{ }^{2+}\right.$ ion [27]. In $\left[\mathrm{Ph}_{4} \mathrm{As}\right]_{2}\left[\mathrm{Co}\left(\mathrm{O}_{2} \mathrm{CCF}_{3}\right)_{4}\right]$ [28] $v_{2}$ and $v_{3}$ appears at 1408 and $574 \mathrm{~cm}^{-1}$, respectively. The diffused reflectance spectra of $\left[\mathrm{Me}_{4} \mathrm{~N}\right]_{2}\left[\mathrm{Co}\left(\mathrm{O}_{2} \mathrm{CCBr}_{3}\right)_{4}\right]$ shows $v_{2}$ at 945 and $1230 \mathrm{~cm}^{-1}$ and $v_{3}$ at 570,645 and $695 \mathrm{~cm}^{-1}$ and favour tetrahedral environment around cobalt.

Octahedral and six coordinate nickel(II) complexes exhibit a spectrum involving transitions from ${ }^{3} \mathrm{~A}_{2 g}$ to ${ }^{3} \mathrm{~T}_{2 g}$, ${ }^{3} \mathrm{~T}_{1 g}(\mathrm{~F})$, and ${ }^{3} \mathrm{~T}_{1 g}(\mathrm{P})$ levels. These occur in the range $1420-765,905-495,525-365 \mathrm{~cm}^{-1}$, respectively [29]. Typical nickel(II) complexes have a multiple visible band near $625 \mathrm{~cm}^{-1}$ assigned to ${ }^{3} \mathrm{~T}_{1} \rightarrow{ }^{3} \mathrm{~T}_{1}(\mathrm{P})\left(v_{3}\right)$ transitions. Weak bands on low energy side and on high energy side are assigned as spin forbidden transitions components of ${ }^{1} \mathrm{D}$ and ${ }^{1} \mathrm{G}$, respectively. A near infrared band around $1250 \mathrm{~cm}^{-1}$ is assigned as ${ }^{3} \mathrm{~T}_{1} \rightarrow{ }^{3} \mathrm{~A}_{2}\left(v_{2}\right)$ transition. In certain circumstances the ${ }^{3} \mathrm{~T}_{1} \rightarrow{ }^{3} \mathrm{~T}_{2}\left(v_{1}\right)$ band can also be observed. 
In diffused reflectance spectra of $\left[\mathrm{Me}_{4} \mathrm{~N}\right]_{2}\left[\mathrm{Ni}\left(\mathrm{O}_{2} \mathrm{CCBr}_{3}\right)_{4}\right]$, $v_{3}$ and $v_{2}$ appear at 545 and $1135 \mathrm{~cm}^{-1}$ with probable assignment of charge transfer band at $430 \mathrm{~cm}^{-1}$ [29]. Thus, a tetrahedral environment is favoured around nickel atom.

Tetragonally distorted, six coordinate copper(II) complexes give rise to one absorption band in the visible region near $625 \mathrm{~cm}^{-1}$ which is often resolved into three components and exhibit a broad tail into the near infrared region [28]. Regular tetrahedral copper(II) complexes are expected to give a single broad band in the near infrared region and to be blank between $1000-500 \mathrm{~cm}^{-1}$. Thus $\mathrm{Cs}_{2} \mathrm{CuCl}_{4}$ shows band at $1111 \mathrm{~cm}^{-1}$ and $\mathrm{Cs}_{2} \mathrm{CuBr}_{4}$ at $1250 \mathrm{~cm}^{-1}$, respectively [30, 31]. Neither complex shows any more absorption band below $500 \mathrm{~cm}^{-1}$. A single band at $1690 \mathrm{~cm}^{-1}\left(\mathrm{~d}_{z 2} \rightarrow \mathrm{d}_{x y}\right)$ in the diffused reflectance spectrum of $\left[\mathrm{Me}_{4} \mathrm{~N}\right]_{2}\left[\mathrm{Cu}\left(\mathrm{O}_{2} \mathrm{CCBr}\right)_{4}\right]$ favours tetrahedral environment around copper atom.

The high spin manganese(II) compounds are expected to show magnetic moments very close to spin only value of 5.92 B.M. and independent of temperature, irrespective of whether the ligand arrangement is octahedral, tetrahedral, or is of lower symmetry. Magnetic moment of $\left[\mathrm{Me}_{4} \mathrm{~N}\right]_{2}\left[\mathrm{Mn}\left(\mathrm{O}_{2} \mathrm{CCBr}_{3}\right)_{4}\right]$ is 6.15 B.M. which is very close to spin only value.

The ground term for a tetrahedral cobalt(II) complexes is ${ }^{4} \mathrm{~A}_{2}$ and the magnetic moment values of four coordinate high spin cobalt(II) complexes fall in the range of 4.19 to 4.90 B.M.. The complex $\left[\mathrm{Me}_{4} \mathrm{~N}\right]_{2}\left[\mathrm{Co}\left(\mathrm{O}_{2} \mathrm{CCBr}_{3}\right)_{4}\right]$ has magnetic moment value of $4.27 \mathrm{BM}$, close to $4.5 \mathrm{BM}$ reported for analogous compounds.

${ }^{3} \mathrm{~T}_{1}$ is the ground state for tetrahedral nickel(II) complexes and it is anticipated that tetrahedral complex should show magnetic moment between 3.2 BM to 4.0 BM at room temperature [19]. Magnetic moment value of 3.28 $\mathrm{BM}$ for $\left[\mathrm{Me}_{4} \mathrm{~N}\right]_{2}\left[\mathrm{Ni}\left(\mathrm{O}_{2} \mathrm{CCBr}_{3}\right)_{4}\right]$ is well in the expected range.

The $\left[\mathrm{Me}_{4} \mathrm{~N}\right]_{2}\left[\mathrm{Cu}\left(\mathrm{O}_{2} \mathrm{CCBr}_{3}\right)_{4}\right]$ has magnetic moment value of $2.0 \mathrm{BM}$ at room temperature and is well in the given range. Thus on the basis of infrared, electronic spectra and magnetic moment of $\left[\mathrm{Me}_{4} \mathrm{~N}\right]_{2}\left[\mathrm{Cu}\left(\mathrm{O}_{2} \mathrm{CCBr}_{3}\right)_{4}\right]$ it may be concluded that unlike tetranitrato metal(II) complexes, these have tetrahedral environment around central metal atom.

All attempts made to prepare the single crystal of these complexes were failed probably due to their insolubility in most of the organic solvents. Therefore, we could not carry out their $X$-ray studies in order to throw more light on the nature of their structure.

TG-DTG curves of $\left[\mathrm{Me}_{4} \mathrm{~N}\right]_{2}\left[\mathrm{M}\left(\mathrm{O}_{2} \mathrm{CCBr}_{3}\right)_{4}\right]$ where $\mathrm{M}=$ $\mathrm{Mn}, \mathrm{Cu}, \mathrm{Ni}, \mathrm{Co}$ are similar and show that they decompose in similar manner in two steps. However, these steps overlap (as shown by DTG curves). They begin to lose weight on heating above $45^{\circ} \mathrm{C}$. The weight loss is slow at the beginning but becomes rapid around $145^{\circ} \mathrm{C}$. The formation of final residue, metal oxide, is complete at about $380^{\circ} \mathrm{C}$. Total loss in weight in each case is in agreement with the value calculated on the basis of their proposed formulae. A typical curve for $\left[\mathrm{Me}_{4} \mathrm{~N}\right]_{2}\left[\mathrm{Mn}\left(\mathrm{O}_{2} \mathrm{CCBr}_{3}\right)_{4}\right]$ is shown in Figure 2. In the first step, there is loss of two molecules of tribromoacetic anhydride followed immediately by the loss of tetramethyl ammonium part as combustible material (weight loss, observed: 93.10\%; Calculated: 94.50\%).

The presence of tribromoacetic anhydride was characterized from the infrared spectrum of the trapped volatiles in a separate experiment.

\section{Acknowledgment}

J. K. Puri, former Professor and Head Inorganic Chemistry, Punjab University Chandigarh (India), is thankful to the University Grant Commission for the award of Emeritus Professor Fellow 2010 in order to continue his research.

\section{References}

[1] J. K. Puri, J. Kaur, V. Sharma, and J. M. Miller, "Solvolytic behaviour and the solubilities of various inorganic compounds, lewis acids and bases in fused monobromo acetic acid solvent system-II," Polyhedron, vol. 2, no. 12, pp. 1287-1295, 1983.

[2] J. K. Puri, V. K. Vats, H. Mandal, and J. M. Miller, "Solvolytic reactions of Lewis acids in monobromoacetic acid and the nature of the solvolysed products," Inorganica Chimica Acta, vol. 97, no. 2, pp. 205-210, 1985.

[3] J. K. Puri, J. Kaur, V. Sharma, and J. M. Miller, "Preparation of metal bromoacetates from other salts by Solvolytic reactions in fused monobromoacetic acid," Polyhedron, vol. 4, no. 7, pp. 1253-1257, 1985.

[4] J. K. Puri and J. M. Miller, "Solvolytic reactions of Lewis acids in dibromoacetic acid and the characterization of the solvolysed products," Inorganica Chimica Acta, vol. 101, no. 2, pp. 135-140, 1985.

[5] J. K. Puri, V. K. Vats, and V. Sharma, "Oxidation-reduction reaction and analysis of thiourea, hydrazine and ascorbic acid in monobromoacetic acid," Indian Journal of Chemistry, vol. 25, pp. 565-570, 1986.

[6] J. K. Puri, V. K. Vats, and A. Miglani, "Syntheses and characterization of aluminium(III), iron(III), and copper(II) monobromoacetates and their complexes with organic bases," Synthesis and Reactivity in Inorganic and Metal-Organic Chemistry, vol. 31, no. 6, pp. 1063-1084, 2001.

[7] J. K. Puri, V. Sharma, and V. K. Vats, "Physico-chemical studies of various protonic acids, bases and salts in monobromoacetic acid," in Proceedings of the 5th Annual Conference of the Indian Council of Chemists, Sindri, India, 1985.

[8] J. K. Puri, V. K. Vats, and A. Miglani, "Synthesis and characterization of titanium(IV), vanadium(III), chromium(III), and manganese(II) monobromoacetates and their complexes with organic bases," Synthesis and Reactivity in Inorganic and MetalOrganic Chemistry, vol. 31, no. 3, pp. 471-489, 2001.

[9] F. Calderazzo, N. Donati, U. Englert, F. Marchetti, G. Pampaloni, and V. Passarelli, "Synthesis, reactivity and structures of mono- and dihaloacetato complexes of copper(I) and copper(II)," Inorganica Chimica Acta, vol. 346, pp. 100-110, 2003.

[10] R. Kruszynski, "Synthesis of coordination compounds via dehalogenation of zinc bromoacetate in presence of some amines," Inorganica Chimica Acta, vol. 371, no. 1, pp. 111-123, 2011.

[11] D. Nicholls, J. C. Bailar, H. J. Emelleys, R. Nyholm, and A. F. Trotman-Dickenson, Eds., Comprehensive Inorganic Chemistry, Pergaman, New York, NY, USA, 1973. 
[12] R. C. Paul, R. C. Narula, and S. K. Vasisht, "Iron(III) acetates," Transition Metal Chemistry, vol. 3, no. 1, pp. 35-38, 1978.

[13] H. Funk and M. Demmel, "Über die Einwirkung von wasserfreiem Eisen-III-chlorid auf wasserfreie Essigsäure und Ameisensäure," Zeitschrift Für Anorganische Und Allgemeine Chemie, vol. 227, pp. 94-102, 1936.

[14] D. W. A. Sharp, D. H. Brown, K. C. Moss, and M. J. Baillie, "Anhydrous metal trifluoroacetates," Journal of the Chemical Society A, pp. 3110-3114, 1968.

[15] C. Oldhan, "Complexes of simple carboxylic acids," in Progress in Inorganic Chemistry, F. A. Cotton, Ed., vol. 10, pp. 223-258, Inter Science Evseceme, 1968.

[16] D. M. Adams, J. Chatt, J. M. Davidson, and J. Gerratt, "The far-infrared spectra $\left(190-460 \mathrm{~cm}^{-1}\right)$ of tetraethylammonium salts of some complex chlorides and bromides," Journal of the Chemical Society, pp. 2181-2188, 1963.

[17] E. Rabinowitch and W. H. Stockmayer, "Association of ferric ions with chloride, bromide and hydroxyl ions (A spectroscopic study)," Journal of the American Chemical Society, vol. 64, no. 2, pp. 335-347, 1942.

[18] R. J. H. Clark, "Metal-halogen stretching frequencies in inorganic complexes," Spectrochimica Acta, vol. 21, no. 5, pp. 955-963, 1965.

[19] B. N. Figgis, J. Lewis, and F. A. Cotton, "The magnetic properties of transition metal complexes," in Progress in Inorganic Chemistry, vol. 6, pp. 37-239, 1964.

[20] B. N. Figgis, A. Earnshaw, and J. Lewis, "Chemistry of polynuclear compounds. Part VI. Magnetic properties of trimeric chromium and iron carboxylates," Journal of the Chemical Society A, pp. 1656-1663, 1966.

[21] F. A. Cotton and G. Wilkinson, "Advance Inorganic Chemistry," Welley Eastern, New Delhi, India, 1978.

[22] J. K. Puri, H. Anand, and A. Miglani, "Preparation and characterization of complexes niobium(V), tantalum(IV) and tungstun(VI) mono, di-, and tribromoacetates," Oriental Journal of Chemistry, vol. 18, p. 445, 2002.

[23] J. K. Puri, V. K. Vats, and A. Miglani, "Syntheses and characterization of aluminium(III), iron(III), and copper(II) monobromoacetates and their complexes with organic bases," Synthesis and Reactivity in Inorganic and Metal-Organic Chemistry, vol. 31, no. 6, pp. 1063-1084, 2001.

[24] D. Forster and D. M. L. Goodgame, "Electronic spectra and magnetic properties of some isothiocyanate complexes of manganese and iron," Journal of the Chemical Society, pp. 268-274, 1965.

[25] A. B. P. Lever, in Inorganic Electronic Spectroscopy, p. 322, Elsevier, New York, NY, USA, 1968.

[26] F. A. Cotton, D. M. L. Goodgame, and M. Goodgame, "The electronic structures of tetrahedral cobalt(II) complexes," Journal of the American Chemical Society, vol. 83, no. 23, pp. 4690-4699, 1961.

[27] J. T. Donoghne and R. S. Drago, "Non-aqueous coordination phenomena-complexes of hexamethylphosphoramide," Inorganic Chemistry, vol. 1, p. 866, 1962.

[28] A. B. P. Lever, in InorganicElectronic Spectroscopy, p. 341, Elsevier, New York, NY, USA, 1968.

[29] D. M. L. Goodgame, M. Goodgame, and F. A. Cotton, "Electronic spectra of some tetrahedral nickel(II) complexes," Journal of the American Chemical Society, vol. 83, no. 20, pp. 4161-4167, 1961.
[30] A. G. Karipides and T. S. Piper, "Crystal spectrum of $\mathrm{Cs}_{2} \mathrm{CuBr}_{4}$ ", Inorganic Chemistry, vol. 1, p. 970, 1962.

[31] W. E. Hatfield and T. S. Piper, "Spectral and magnetic properties of chlorocuprates," Inorganic Chemistry, vol. 3, no. 6, pp. 841-843, 1964. 

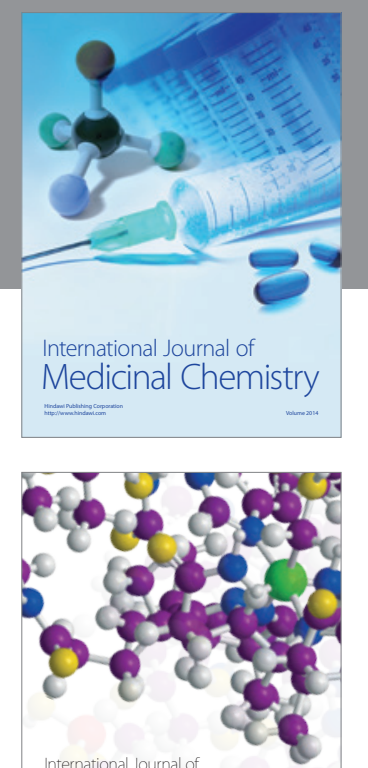

\section{Carbohydrate} Chemistry

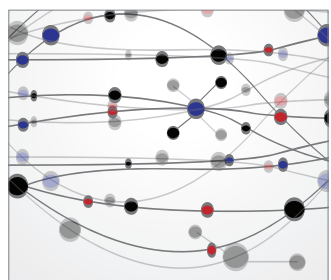

The Scientific World Journal
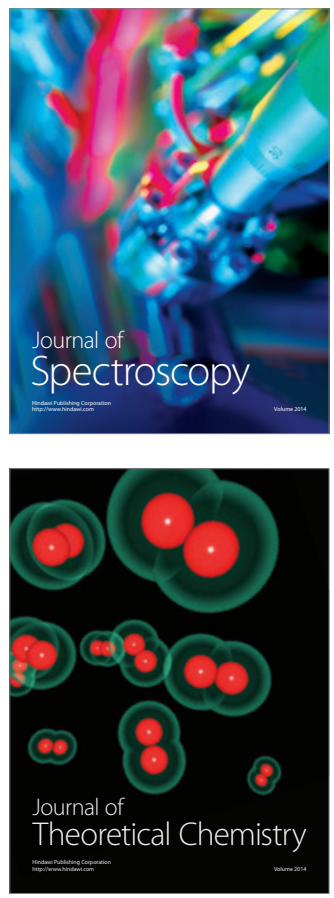
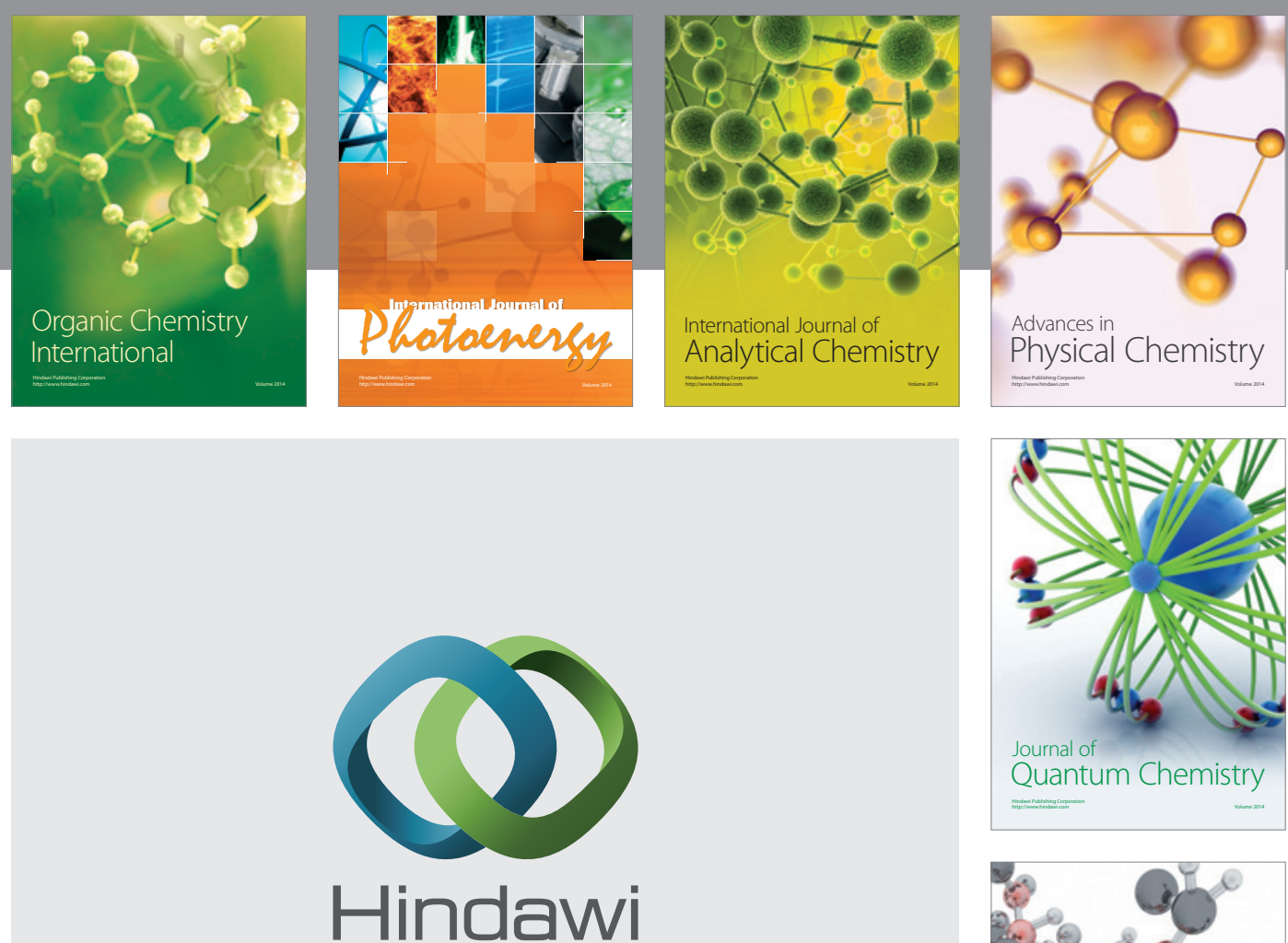

Submit your manuscripts at

http://www.hindawi.com

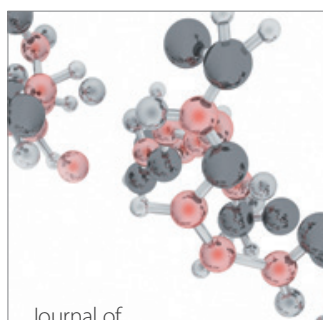

Analytical Methods

in Chemistry

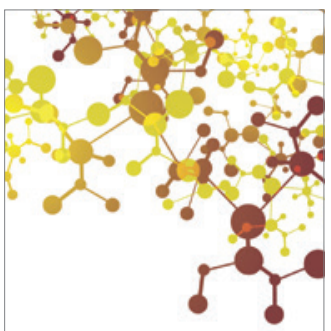

Journal of

Applied Chemistry

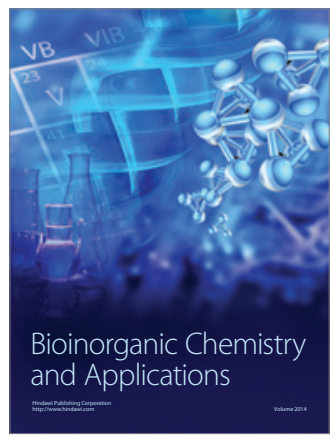

Inorganic Chemistry
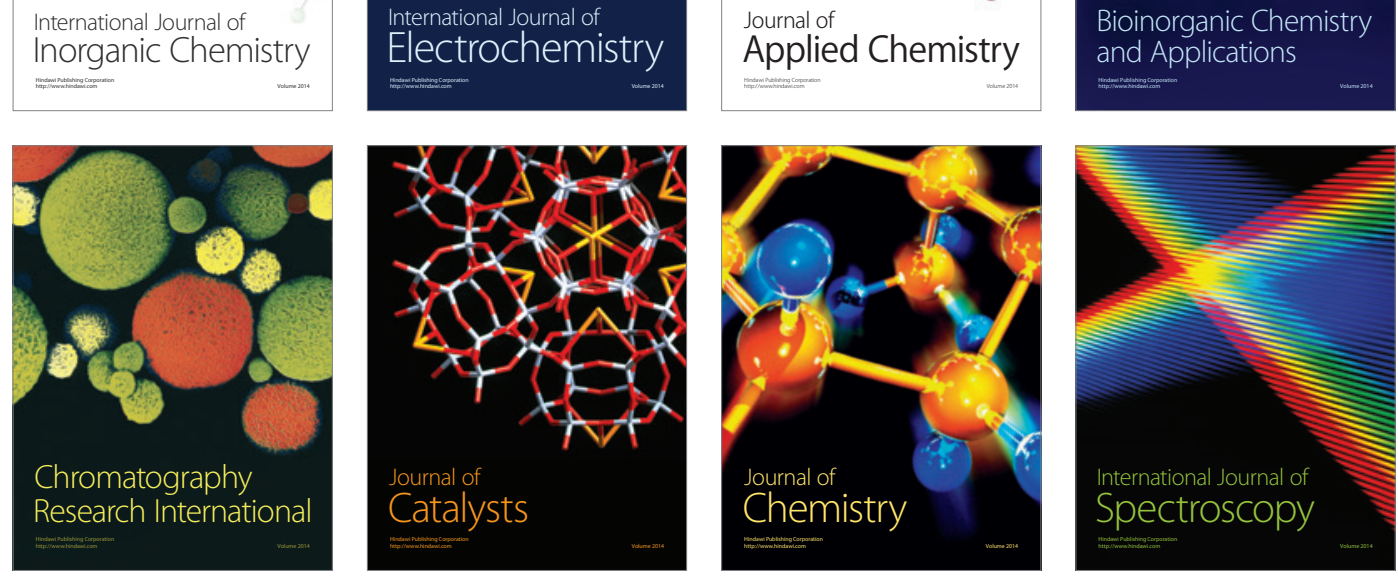